\title{
УСПАДКУВАННЯ СТІЙКОСТІ ГІБРИДАМИ ПЕРШОГО ПОКОЛІННЯ ПШЕНИЦІ ТВЕРДОЇ ЯРОЇ ДО ТВЕРДОЇ САЖКИ
}

Т. В. Бабушкіна, В. П. Петренкова, О. В. Голік

Інститут рослинництва ім. В. Я. Юр'єва НААН

Наведено результати досліджень стійкості селекційного матеріалу пшениці твердої ярої до збудника твердої сажки. Виділено джерела стійкості і визначено рівень прояву фенотипового домінування ознаки стійкості до збудника твердої сажки.

Пшениця тверда яра, $F_{1}$, гібрид, успадкування, тверда сажка, джерело стійкості

У теперішній час у сучасних сортів успадкування ознаки стійкості до збудників хвороб набуває такого ж важливого значення, як продуктивність $\mathrm{i}$ якість урожаю. Використання стійких до хвороб сортів у виробництві має ряд суттєвих переваг: по-перше, це зменшення втрат урожаю від хвороб, підвищення якості отриманої продукції, в чому і заключається селекційна цінність таких сортів; по-друге, стійкі форми рослин обмежують рівень розвитку патогенів, завдяки чому знижується кількість їх інфекційного початку; по-третє, застосування толерантних сортів знижує використання хімічних засобів захисту [1].

Слід зазначити, що в останні роки знизився контроль за якістю протруювання насіння, що сприяє зараженню збудником твердої сажки. Як наслідок заражені рослини слабкі, посіви зріджуються, забур'янюються, що призводить до значних втрат урожаю. Прямі втрати зерна від сажки в роки масового ураження посівів сягають $30 \%$.

Селекція пшениці ярої на стійкість забезпечує покращення фітосанітарного стану пшеничного поля. Цей напрямок актуальний у всьому світі, оскільки обумовлений економічними та екологічними факторами.

Для забезпечення селекційних програм джерелами та донорами стійкості до твердої сажки необхідне планомірне їх визначення і подальше всебічне вивчення. Відомо, що популяція твердої сажки в Україні представлена двома видами - Tilletia caries i T. laevis з широким спектром рас.

На теперішній час в центральній частині України високо-вірулентну расу 37 цілком замінила менш вірулентна раса 32 [1]. На півдні на зміну слабковірулентній расі 11 прийшла високовірулентна раса 40 . У східній частині лісостепу домінує раса 11 [2].

За нашими даними у Харківській області популяція збудника твердої сажки (T. caries) в останні роки представлена переважно расами $3,5,16$, які

(C) Т. В. Бабушкіна, В. П. Петренкова, О. В. Голік. 2012. ISSN 0582-5075. Селекція і насінництво. 2012. Випуск 102. 
$\epsilon$ слабко вірулентними, але досить агресивними, висока стійкість проти яких забезпечується багатьма з відомих генів Bt.

Метою наших досліджень є створення вихідного матеріалу для селекції пшениці ярої з певною стійкістю до твердої сажки. Дослідження проводили в інфекційних розсадниках наукової сівозміни Інституту рослинництва ім. В. Я. Юр’єва впродовж 2009-2011 рр.

Для визначення стійкості пшениць до твердої сажки нами щорічно створюється інфекційний фон: насіння сортозразків інокулюється спорами збудника твердої сажки місцевої популяції і висівається у спеціальному розсаднику для подальшого обліку [3]. Для контролю за якістю інокулювання рослин збудником твердої сажки та умовами проявлення і поширення iii використовували індикатори сприйнятливості до хвороби, підібрані раніше за багаторічними даними, які висівали в інфекційних розсадниках через кожні 20 зразків.

Для запланованого вивчення генетичних особливостей та характеру успадкування стійкості до збудника хвороби в попередні роки провели ряд схрещувань за схемою стійкий (джерело) / сприйнятливий. Отримано насіння та висіяно $\mathrm{F}_{1} 23$ експериментальних гібридних комбінацій, створені за участю джерел стійкості. Ступінь фенотипового домінування кількісних ознак визначали за Н. И. Корсаковым, Б. В. Ричиным [4].

Результати наших досліджень, проведені у 2009-2011 рр. свідчать, що серед оцінених 200 колекційних і селекційних сортів та ліній пшениці твердої ярої лише 3,4 \% характеризуються стійкістю до патогена. Результативність селекційної роботи на стійкість до збудника твердої сажки ускладнюється обмеженою кількістю ефективних генів стійкості та низькою селекційною цінністю донорів ознаки.

В 2009-2011 рр. на стійкість до твердої сажки в інфекційному розсаднику інституту було вивчено 107 селекційних сортів та ліній пшениці твердої ярої. На фоні ураженості сприйнятливих до хвороби стандартів визначено джерела стійкості. Так стійкістю до твердої сажки характеризуються сім зразків пшениці твердої ярої походженням із України, які були залучені в схрещування (табл. 1).

Визначення донорських властивостей у виділених джерел стійкості $\epsilon$ завершальним етапом досліджень за будь - яким напрямком, а за стійкістю до збудників хвороб дані дослідження є обов'язковими, так як наявність ознаки в нових сортах забезпечує високу продуктивність і якість.

У 2011 році проводили гібридологічний аналіз для визначення генетичних особливостей стійкості до твердої сажки (T. tritici) двох сортів 3 України (Нащадок, Чадо) та п’яти ліній лабораторії селекції пшениці ярої IP (04-207, 05-1090, 05-354, 06-554, 06-557).

Аналіз результатів оцінки ступеня фенотипового домінування успадкуванні стійкості до твердої сажки у $\mathrm{F}_{1}$ гібридів від батьківських форм (рис. 1) свідчить, що в межах даної сукупності успадкування відбувається за спектром типів: позитивне наддомінування (гетерозис), проміжне успадкування, негативне наддомінування (депресія). Це підтверджує і діапазон чисельних значень коефіцієнту домінування hр - від 1,9 до -1,8 \%. 
Зразки пшениці твердої ярої - джерела стійкості до твердої сажки (збудник T. caries)

\begin{tabular}{|c|c|c|c|}
\hline \multirow{2}{*}{ Сорт, лінія } & \multicolumn{3}{|c|}{ Стійкість до твердої сажки, бал / ураженість, \% } \\
\cline { 2 - 4 } & $2008 \mathrm{p}$. & $2009 \mathrm{p}$. & $2010 \mathrm{p}$. \\
\hline Нащадок & $7 / 5,3$ & $7 / 7,0$ & $8 / 4,9$ \\
\hline Чадо & $8 / 1,7$ & $8 / 3,9$ & $7 / 6,5$ \\
\hline $04-207$ & $8 / 0,8$ & $7 / 7,5$ & $8 / 1,8$ \\
\hline $05-1090$ & $7 / 8,8$ & $7 / 9,5$ & $8 / 3,4$ \\
\hline $05-354$ & $8 / 5,0$ & $7 / 8,2$ & $8 / 0,4$ \\
\hline $06-554$ & $7 / 7,0$ & $8 / 3,5$ & $9 / 0$ \\
\hline $06-557$ & $7 / 10,0$ & $8 / 0,9$ & $9 / 0$ \\
\hline
\end{tabular}

Так, серед гібридів першого покоління, в 23 гібридних комбінаціях 14 мали позитивне наддомінування за стійкістю до твердої сажки. Вони входять в діапазон чисельних значень коефіцієнту домінування $\mathrm{hp}>1$ від 1,1 до 1,9 і складають 61,0 \% від сукупності досліджених гібридів (рис. 1).

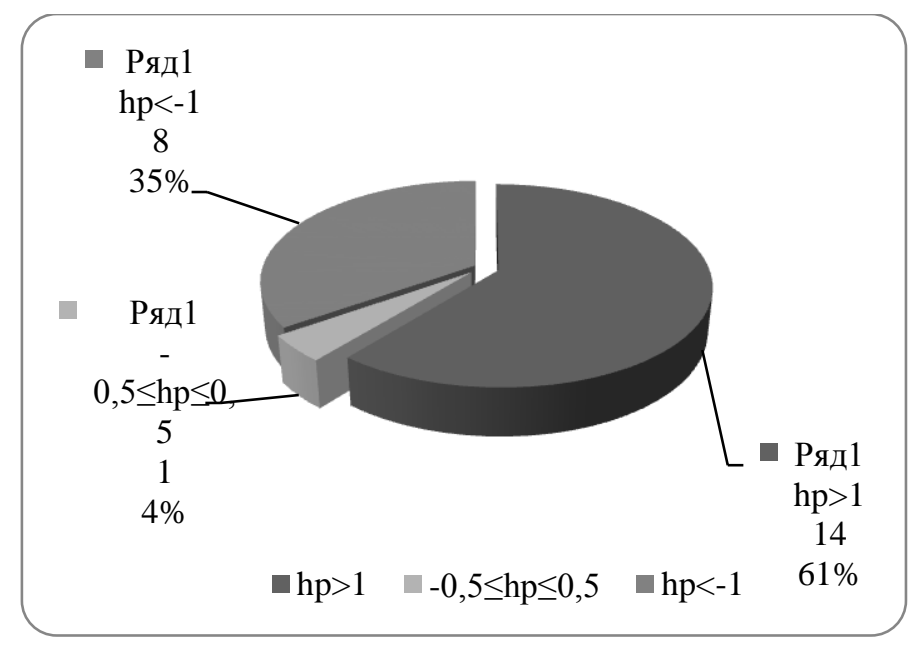

Рис. 1. Оцінка ступеня фенотипового домінування в успадкуванні твердої сажки у $\mathrm{F}_{1}$ гібридів

У комбінації 05-1090 / Харківська 39 виявлено проміжний характер успадкування стійкості до твердої сажки $(-0,5 \leq h \mathrm{p} \leq 0,5)$, входить в діапазон чисельних значень коефіцієнту домінування показник $\mathrm{hp}=-0,5$, що становить $4,0 \%$.

У 35,0 \% гібридних потомств (вісім комбінацій) відмічено негативне наддомінування (депресію) за досліджуваною ознакою (hp=-1,1...- 1,8). 
Таблиця 2

Результати гібридологічного аналізу $\mathrm{F}_{1}$ в комбінаціях за участю джерел стійкості до твердої сажки, 2011 p.

\begin{tabular}{|c|c|c|c|c|c|}
\hline \multirow[t]{2}{*}{ Гібрид } & \multicolumn{3}{|c|}{$\begin{array}{c}\text { Стійкість до твердої } \\
\text { сажки, \% / бал }\end{array}$} & \multirow{2}{*}{$\begin{array}{c}\text { hр* } \\
\text { ознаки } \\
\text { стійкості }\end{array}$} & \multirow{2}{*}{$\begin{array}{c}\text { Тип } \\
\text { успадкування }\end{array}$} \\
\hline & q & $\hat{0}$ & $\mathrm{~F}_{1}$ & & \\
\hline 06-554/04-259 & $92,9 / 8$ & $60,3 / 4$ & $50,7 / 3$ & $-1,6$ & депресія \\
\hline 06-557/04-259 & $90,5 / 8$ & $60,3 / 4$ & $48,1 / 3$ & $-1,8$ & депресія \\
\hline Нащадок/Харківська 18 & $90,8 / 8$ & $49,8 / 3$ & $47,6 / 3$ & $-1,1$ & депресія \\
\hline Нащадок/Харківська 27 & $90,8 / 7,8$ & $65,8 / 3$ & $59,2 / 3$ & $-1,5$ & депресія \\
\hline 04-207/Харківська 39 & $94,9 / 7,5$ & $63,2 / 3$ & $49,8 / 3$ & $-1,8$ & депресія \\
\hline 06-554/Харківська 39 & $92,9 / 7,5$ & $63,2 / 4$ & $57,5 / 3$ & $-1,4$ & депресія \\
\hline Нащадок/Харківська 39 & $90,8 / 7,5$ & $63,2 / 4$ & $58,1 / 3$ & $-1,4$ & депресія \\
\hline 05-354/Харківська 39 & $93,2 / 7,5$ & $63,2 / 4$ & $58,5 / 3$ & $-1,3$ & депресія \\
\hline 05-1090/Харківська 39 & $92,2 / 7,5$ & $63,2 / 4$ & $70,8 / 4$ & $-0,5$ & $\begin{array}{c}\text { проміжне } \\
\text { успадкування }\end{array}$ \\
\hline 05-354/04-259 & $93,2 / 8$ & $60,3 / 4$ & $95,5 / 8$ & 1,1 & гетерозис \\
\hline Чадо/04-259 & $93,2 / 8$ & $60,3 / 4$ & $95,2 / 8$ & 1,1 & гете \\
\hline $05-354 / 05-335$ & $93,2 / 8$ & $69,5 / 4$ & $97,5 / 8$ & 1,4 & гетерозис \\
\hline 06-554/05-335 & $92,9 / 7,5$ & $69,5 / 4$ & $96,6 / 8$ & 1,3 & гетерозис \\
\hline Чадо/05-335 & $93,2 / 8$ & $69,5 / 4$ & $98,2 / 8$ & 1,4 & гетерозис \\
\hline 05-1003/Харківська 18 & $91,1 / 8$ & $49,8 / 3$ & $99,2 / 8$ & 1,4 & гетерозис \\
\hline Нащадок/04-259 & $90,8 / 8$ & $60,3 / 4$ & $100 / 9$ & 1,6 & гетерозис \\
\hline 06-557/05-335 & $90,5 / 7,5$ & $69,5 / 4$ & $100 / 9$ & 1,9 & гетерозис \\
\hline Нащадок/05-335 & $90,8 / 8$ & $69,5 / 4$ & $100 / 9$ & 1,9 & гетерозис \\
\hline \begin{tabular}{|l|}
$05-533 / 06-34$ \\
\end{tabular} & $90,4 / 8$ & $66,3 / 3$ & $100 / 9$ & 1,8 & гетерозис \\
\hline 05-1090/Харківська 27 & $92,2 / 7,8$ & $65,8 / 4$ & $100 / 9$ & 1,6 & гетерозис \\
\hline 04-207/Харківська 27 & $94,9 / 7,8$ & $65,8 / 4$ & $100 / 9$ & 1,4 & гетерозис \\
\hline Чадо/Харківська 27 & $93,2 / 7,8$ & $65,8 / 4$ & $100 / 9$ & 1,5 & гетерозис \\
\hline Чадо/Харківська 39 & $93,2 / 7,5$ & $63,2 / 3$ & $100 / 9$ & 1,5 & гетерозис \\
\hline
\end{tabular}

Примітка* - ступінь фенотипового домінування

Таким чином, аналіз результатів оцінки ступеня фенотипового домінування в успадкуванні стійкості до твердої сажки у $\mathrm{F}_{1}$ гібридів від батьківських форм показує, що 61,0 \% досліджених гібридів (14 гібридних комбінацій) мали позитивне наддомінування за стійкістю до твердої сажки. Одна гібридна комбінація 05-1090 / Харківська 39 мала проміжний характер успадкування і у восьми гібридних потомств $(35,0$ \%) відмічено негативне наддомінування стійкості до патогена, тобто сприйнятливість. 
Висновки. За результатам трирічної оцінки селекційного матеріалу пшениці ярої виділено джерела стійкості до збудника твердої сажки: два сорти з України (Нащадок, Чадо) та п’ять ліній лабораторії селекції пшениці ярої IP (04-207, 05-1090, 05-354, 06-554, 06-557).

При залученні у схрещування різних за ступенем стійкості до твердої сажки материнських та батьківських форм відмічено повне та часткове успадкування ознаки стійкості чи сприйнятливості до збудника твердої сажки.

\section{Список використаних джерел}

1. Кривченко В. И. Устойчивость зерновых колосовых к возбудителям головневых болезней / В. И. Кривченко. - М. Колос, 1984. - 304 с.

2. Ращенко Л. М. Тверда сажка озимої пшениці та обгрунтування імунологічних методів захисту: дис. ... канд. с.-г. наук / Л. М. Ращенко. - Київ, 2003. $140 \mathrm{c}$.

3. Методы селекции и оценка устойчивости пшеницы и ячменя в странах членах СЭВ / [Бабаянц Л. Т. и др.] - Прага. - 1988. - 321 с.

4. Генетический анализ качественных признаков растений : методические указания. - Л.: ВИР, 1980. - 29 с.

Приведены результаты исследований селекционного материала пшеницы яровой по устойчивости к возбудителю твердой головни. Выделены источники устойчивости и установлен уровень проявления фенотипического доминирования признака устойчивости к возбудителю твердой головни.

The results on the studies of resistance in the breeding material of spring wheat to stinking smut pathogens are presented. The sources of resistance are detected and the level of manifestation of phenotypic dominance of resistance to stinking smut agent is determined. 